\title{
Neuroimaging in Zoonotic Outbreaks Affecting the Central Nervous System: Are We Fighting the Last War?
}

\author{
(1) G.X. Goh, ㅈ. Tan, DB.S.P. Ang, (1) L.F. Wang, and (1)C.C. Tchoyoson Lim
}

History doesn't repeat itself, but it often rhymes.

Mark Twain

\begin{abstract}
SUMMARY: When preparing for the coronavirus disease 2019 pandemic and its effects on the CNS, radiologists should be familiar with neuroimaging appearances in past zoonotic infectious disease outbreaks. Organisms that have crossed the species barrier from animals to humans include viruses such as Hendra, Nipah, Severe Acute Respiratory Syndrome, and influenza, as well as bacteria and others. Brain CT and MR imaging findings have included cortical abnormalities, microinfarction in the white matter, largevessel occlusion, and features of meningitis. In particular, the high sensitivity of diffusion-weighted MR imaging in detecting intracranial abnormalities has been helpful in outbreaks. Although the coronaviruses causing the previous Severe Acute Respiratory Syndrome outbreak and the current coronavirus disease 19 pandemic are related, it is important to be aware of their similarities as well as potential differences. This review describes the neuroimaging appearances of selected zoonotic outbreaks so that neuroradiologists can better understand the current pandemic and potential future outbreaks.
\end{abstract}

ABBREVIATIONS: COVID-19 = coronavirus disease 2019; HeV = Hendra virus; MERS-CoV = Middle East respiratory syndrome coronavirus; NiV = Nipah virus; SARS-CoV-2 = Severe Acute Respiratory Syndrome coronavirus 2

C urrently, the coronavirus disease 2019 (COVID-19) pandemic is sweeping across the world, caused by the emerging novel zoonotic virus Severe Acute Respiratory Syndrome coronavirus 2 (SARS-CoV-2). ${ }^{1}$ First detected in Wuhan, China, in late 2019, COVID-19 (the clinical syndrome caused by the virus) has resulted in high mortality and morbidity, overwhelming the health services as well as causing severe disruption to the economy in many parts of the world. ${ }^{1,2}$ In the past 20 years, there have been increasing epidemic outbreaks of zoonotic diseases, including coronaviruses and various other pathogens. ${ }^{3,4}$ Zoonoses often present with neurologic symptoms and imaging changes on CT and MR imaging; hence, it is important for neuroradiologists to be familiar with the imaging findings in past outbreaks in addition to obtaining up-to-date information on the current one. ${ }^{5,6}$ This review is based on a literature review and the authors' ongoing research and introduces the

Received May 19, 2020; accepted after revision June 15.

From the Emerging Infectious Diseases Programme (G.X.G., L.-F.W.), Duke-NUS Medical School, Singapore; Departments of Neurology (K.T.) and Neuroradiology (C.C.T.L.), National Neuroscience Institute and Duke-NUS Medical School, Singapore; Department of Infectious Diseases and Infection Prevention and Control (B.S.P.A.), Tan Tock Seng Hospital, Singapore.

Please address correspondence to C.C. Tchoyoson Lim, MBBS, FRCR (UK), MMed (Diagostic Radiology), Department of Neuroradiology, National Neuroscience Institute, 11 Jalan Tan Tock Seng, Singapore 308433, Republic of Singapore; e-mail: tchoyoson.lim@singhealth.com.sg

- Indicates open access to non-subscribers at www.ajnr.org

http://dx.doi.org/10.3174/ajnr.A6727 zoonotic infections and associated neuroimaging appearances in past outbreaks that have affected the CNS, to improve our understanding of the current pandemic and future zoonotic disease outbreaks.

\section{Emerging Zoonotic Diseases and the CNS}

A zoonotic disease is defined as an infectious agent leaping from an animal reservoir to humans, often caused by mutations that permit accessibility through receptor or immune barriers of the novel host. ${ }^{7}$ In the broadest sense, zoonoses encompass both direct spread from a vertebrate animal to humans, as well as vector-borne diseases that use intermediate arthropod vectors (typically mosquitos, ticks, sand flies, and so on), resulting in indirect spread to humans. Additionally, zoonotic pathogens range from viruses, bacteria, parasites, and fungi to prions. ${ }^{8}$ The global burden of animal-to-human disease transmission is increasing, and up to $76 \%$ of emerging infectious disease events in recent years have been zoonotic in nature. ${ }^{9}$ Historically, the 3 pandemics of greatest significance-the Plague (or "Black Death"), the 1918 Spanish flu, and HIV/AIDS-were all caused by zoonoses or vector-borne diseases, leading to hundreds of millions of deaths worldwide. ${ }^{10}$

In recent decades, bats have emerged as mammalian hosts serving as reservoirs for pathogens of high mortality. Although historically known to transmit rabies virus alongside the order 

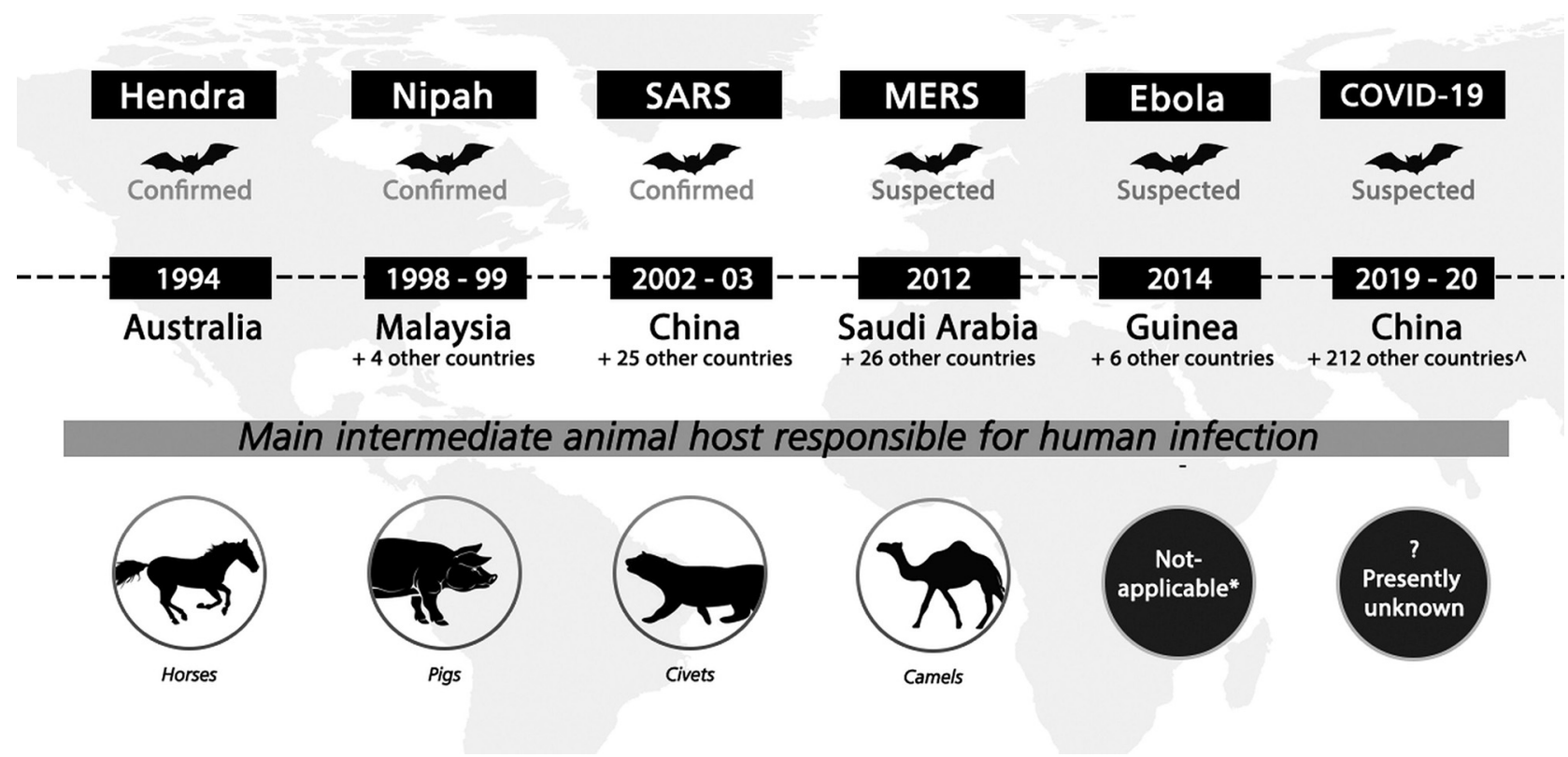

FIG 1. Summary of major emerging zoonotic outbreaks related to bats, 1994-2019. Confirmed bat-borne viruses include Hendra, Nipah, and SARS-CoV-1 viruses; bats are also suspected to be viral reservoirs for MERS, Ebola, and SARS-CoV-2 (cause of the current COVID-19 pandemic) viruses. Years when outbreaks occurred and confirmed or suspected intermediate hosts involved in virus spillover are also shown. ${ }^{*}$ indicates that although the 2014 Ebola outbreak was believed to have started with direct bat-to-human transmission, nonhuman primates have been implicated in previous Ebola outbreaks. ^Data accurate as of May 11, 2020. Reprinted with permission of Duke-NUS Medical School.

Carnivora, bats have now been shown to carry assorted viruses from different families, including zoonotic viruses such as Coronaviridae, Filoviridae, and Paramyxoviridae, among others. ${ }^{11}$ Bats are also a well-recognized reservoir for Lyssaviruses, including the rabies virus and Australian bat lyssavirus, which classically result in encephalitic or paralytic rabies. ${ }^{12}$ Critically, bat-borne viruses cause regular and cyclical outbreaks via zoonotic transmission and spillover into secondary mammalian hosts. Increasing recognition of bats as animal reservoirs of zoonotic pathogens began with the Hendra virus $(\mathrm{HeV})$ outbreak in 1994 and has only since accelerated up to the current COVID-19 pandemic. ${ }^{13,14}$ Other important examples of novel zoonotic virus emergence linked to bats include the 1998 Nipah virus (NiV) disease in pigs in Malaysia, Severe Acute Respiratory Syndrome coronavirus 1 (SARS-CoV) in China in 2002, Middle East respiratory syndrome coronavirus (MERS-CoV) in Saudi Arabia starting in 2012, and devastating outbreaks of filoviruses from 1967 through 2018 (Fig 1). ${ }^{15,16}$

Table 1 shows examples of zoonotic diseases that have been associated with CNS manifestations. Zoonotic diseases with other animal hosts include the 2009 outbreak of zoonotic "swine flu" influenza H1N1 strain and sporadic human cases of avian influenza subtypes $\mathrm{H} 5 \mathrm{~N} 1$ and $\mathrm{H} 9 \mathrm{~N} 2 .{ }^{17}$ Within rodent reservoirs in Europe, the Americas, and Asia, hantaviruses have been found to spill over into humans and may also present with pulmonary and neurologic symptoms. ${ }^{18}$ A large number of CNS infections are vector-borne diseases, notably arthropod-borne Alphaviruses and Flaviviruses. Key examples include the mosquito-borne Japanese encephalitis virus and West Nile virus, dengue, Chikungunya, Zika (responsible for an outbreak in 2015-2016 that caused fetal MR imaging changes), ${ }^{19}$ and tick-borne viruses. A review of vector-
Table 1: Key zoonotic diseases with CNS manifestations

\begin{tabular}{|c|c|c|}
\hline $\begin{array}{l}\text { Pathogen } \\
\text { Type }\end{array}$ & Animal Reservoir & $\begin{array}{c}\text { Zoonotic Species or } \\
\text { Agent }\end{array}$ \\
\hline \multirow[t]{2}{*}{ Viral } & Bats & $\begin{array}{l}\text { Rabies virus (RABV) } \\
\text { Australian bat lyssavirus } \\
\quad(\text { ABLV) } \\
\text { Hendra virus (HeV) } \\
\text { Nipah virus (NiV) } \\
\text { SARS-CoV, MERS-CoV, } \\
\text { SARS-CoV-2 }\end{array}$ \\
\hline & $\begin{array}{l}\text { Bats, primates, duikers } \\
\text { Primates } \\
\text { Rodents } \\
\text { Poultry, swine }\end{array}$ & $\begin{array}{l}\text { Ebola virus (EBOV) } \\
\text { Marburg virus (MARV) } \\
\text { Herpes B virus } \\
\text { Hantavirus } \\
\text { Influenza A virus (H1N1, } \\
\quad \text { H1N2, H3N2, H5N1, } \\
\text { H7N9) }\end{array}$ \\
\hline Bacterial & $\begin{array}{l}\text { Rabbits, rodents } \\
\text { Poultry } \\
\text { Fish }\end{array}$ & $\begin{array}{l}\text { Brucella species } \\
\text { Leptospira interrogans } \\
\text { Coxiella burnetii } \\
\text { Francisella tularensis } \\
\text { Chlamydia psittaci } \\
\text { Streptococcus iniae }\end{array}$ \\
\hline Parasitic & $\begin{array}{l}\text { Felines } \\
\text { Swine } \\
\text { Sheep, cattle }\end{array}$ & $\begin{array}{l}\text { Toxoplasma gondii } \\
\text { Taenia solium } \\
\text { Echinococcus species }\end{array}$ \\
\hline Fungal & $\begin{array}{l}\text { Bats, birds, various } \\
\text { mammals }\end{array}$ & $\begin{array}{l}\text { Histoplasma capsulatum } \\
\text { Cryptococcus } \\
\text { neoformans, } \\
\text { Cryptococcus gattii }\end{array}$ \\
\hline
\end{tabular}

borne CNS diseases is outside the scope of this article, which focuses on zoonotic outbreaks directly from animals to humans. Notably, most recent zoonotic outbreaks reaching regional or global significance appear to be viral in nature. 


\section{Neuroimaging in Recent Zoonotic Infectious Outbreaks Affecting the CNS}

Zoonotic Bat-Borne Henipaviruses: Hendra and Nipah Viruses. A separate genus of Henipavirus within the Paramyxoviridae family was created after the discovery of 2 new viruses causing zoonotic outbreaks, which were named after the $\mathrm{HeV}$ and $\mathrm{NiV}$. $\mathrm{HeV}$ (initially named equine morbillivirus) was isolated during 2 outbreaks in 1994 at a stable in Hendra, a suburb of Brisbane, Australia, causing the deaths of 16 horses, a trainer, and another animal handler. ${ }^{20}$ Ongoing $\mathrm{HeV}$ outbreaks in Australia have been reported, with a total of 94 equine disease cases, 7 human cases, and 4 deaths as of 2015, typically in veterinarians or animal handlers, with a fatality rate of $80 \%$ in horses and $57 \%$ in humans. ${ }^{21,22}$ The virus presents with an acute febrile respiratory disease and neurologic symptoms (eg, confusion, ataxia, and seizures) in humans. Brain MR imaging showed widespread cortical lesions with sparing of the subcortical white matter on T2-weighted images, similar in appearance to subacute sclerosing panencephalitis caused by measles, the prototypic paramyxovirus. $^{21,23}$

$\mathrm{NiV}$, named after the village where the virus was first isolated, caused a larger pig-borne outbreak of fatal encephalitis and pneumonia in 1998. A total of 265 cases of acute NiV encephalitis with 105 deaths were recorded in Malaysia. ${ }^{24}$ The virus crossed the border to neighboring Singapore, which imported live pigs for slaughter, and spread to 11 slaughterhouse workers, of whom 1 died. ${ }^{25,26}$ Patients typically presented with fever, vomiting, headache, and dizziness, which developed into severe encephalitis with altered consciousness, brain stem dysfunction, seizures, and myoclonic jerks. ${ }^{26,27}$ Neurologic involvement was diverse, including aseptic meningitis, diffuse encephalitis, and focal brain stem and cerebellar involvement. Some early cases were initially ascribed to Japanese encephalitis virus, which had previously caused pig-associated outbreaks in Malaysia, but there were many clinical, epidemiologic, and radiologic red flags that helped to differentiate between the diseases.

As transmission was from bats to pigs and subsequently pigs to humans, pig farms were shut and pigs culled in Malaysia. All importation of live pigs and pork products to Singapore from Malaysia was banned, and slaughterhouses closed, ending the outbreak in 1999. Starting in 2001, multiple NiV outbreaks were reported in West Bengal, India, and multiple locations in Bangladesh, with local epidemics spreading as far southward and westward as Kerala. ${ }^{24}$ These outbreaks were caused by direct transmission from bats to humans (via consumption of fresh date palm sap or fruit contaminated by bat secretions or from contact with infected animals) and human-to-human spread of infection (including health care workers). ${ }^{28} \mathrm{NiV}$ outbreaks mainly caused encephalitis, but respiratory symptoms have been reported in from $29 \%$ to two-thirds of cases in different outbreaks. ${ }^{29}$ More recent reports of outbreaks in Mindanao, the Philippines (fatal human encephalitis, influenza-like disease, and meningitis) were spread by diseased horses. ${ }^{30}$

MR imaging among Singaporean patients infected with $\mathrm{NiV}$ showed multifocal, bilateral tiny $(<1 \mathrm{~cm}$ in maximum diameter) abnormalities, more within the subcortical and deep white matter (Fig 2) than the cortex, brain stem, or corpus callosum. Most

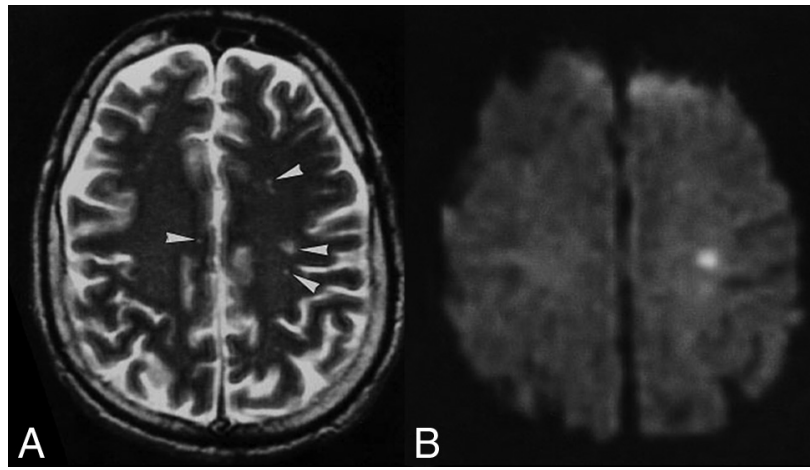

FIG 2. Patient with Nipah virus infection: initial infection. $A$, Multiple punctate white matter lesions (arrowheads) are visible on T2weighted FSE MR image. $B$, The largest lesion is more prominent on corresponding DWI. Images reprinted from Lim et al. ${ }^{31}$

were prominently detected by DWI compared with T2-weighted images, and some lesions enhanced after contrast media injection. $^{31,32}$ In a follow-up MR imaging study among patients in Singapore, multiple small T1-weighted hyperintensities in the cerebral cortex, similar in appearance to laminar cortical necrosis, were noted 1 month after the outbreak, but there were no clinical or radiologic relapse or subacute sclerosing panencephalitis features. These tiny T1-weighted abnormalities also disappeared on later MR imaging studies at 6 months and later (Fig 3). Among a cohort of asymptomatic-but-seropositive Singapore slaughterhouse workers who were exposed to pigs, delayed MR imaging revealed discrete tiny lesions in the brain (but without DWI abnormalities at the late time of acquisition) similar to those detected in symptomatic patients with encephalitis. ${ }^{33}$ In the patients in Singapore who were followed-up, 1 patient developed myelopathic symptoms from a cervical spinal cord lesion; a proportion developed psychiatric features, including depression, personality changes, and deficits in attention and memory.

In contrast, follow-up of patients in Malaysia showed a different neuroimaging pattern of extensive patchy and confluent involvement of the cortex, temporal lobe, and pons on T2weighted images. ${ }^{34}$ In a series of 160 Malaysian survivors of Nipah encephalitis, 12 patients had relapses, and 3 had late-onset encephalitis. ${ }^{35-37}$ Malaysian patients may have been more severely affected than those in Singapore, perhaps because of the nature of their exposure to the virus. ${ }^{29}$ The Singapore MR imaging pattern of tiny DWI abnormalities followed by transient T1 hyperintensities was distinctly different from the characteristic features of herpesvirus and Japanese encephalitis virus and was more consistent with virus-associated microangiopathy and ischemic microinfarction. Postmortem studies performed on Malaysian patients showed both direct neuronal invasion and disseminated microinfarction from vasculitis-induced thrombosis. Small and medium-sized blood vessels in other organs also had similar vasculitic lesions, resulting in endothelial multinucleated syncytia and fibrinoid necrosis. ${ }^{24,38}$ In addition, postmortem examination of 2 fatal cases of $\mathrm{HeV}$ infections in Australia showed similar findings, which suggested that the pathologic mechanisms might be similar in $\mathrm{HeV}$ and $\mathrm{NiV}$ and supporting ischemic microinfarction as a partial explanation for MR imaging findings. ${ }^{39,40}$ 


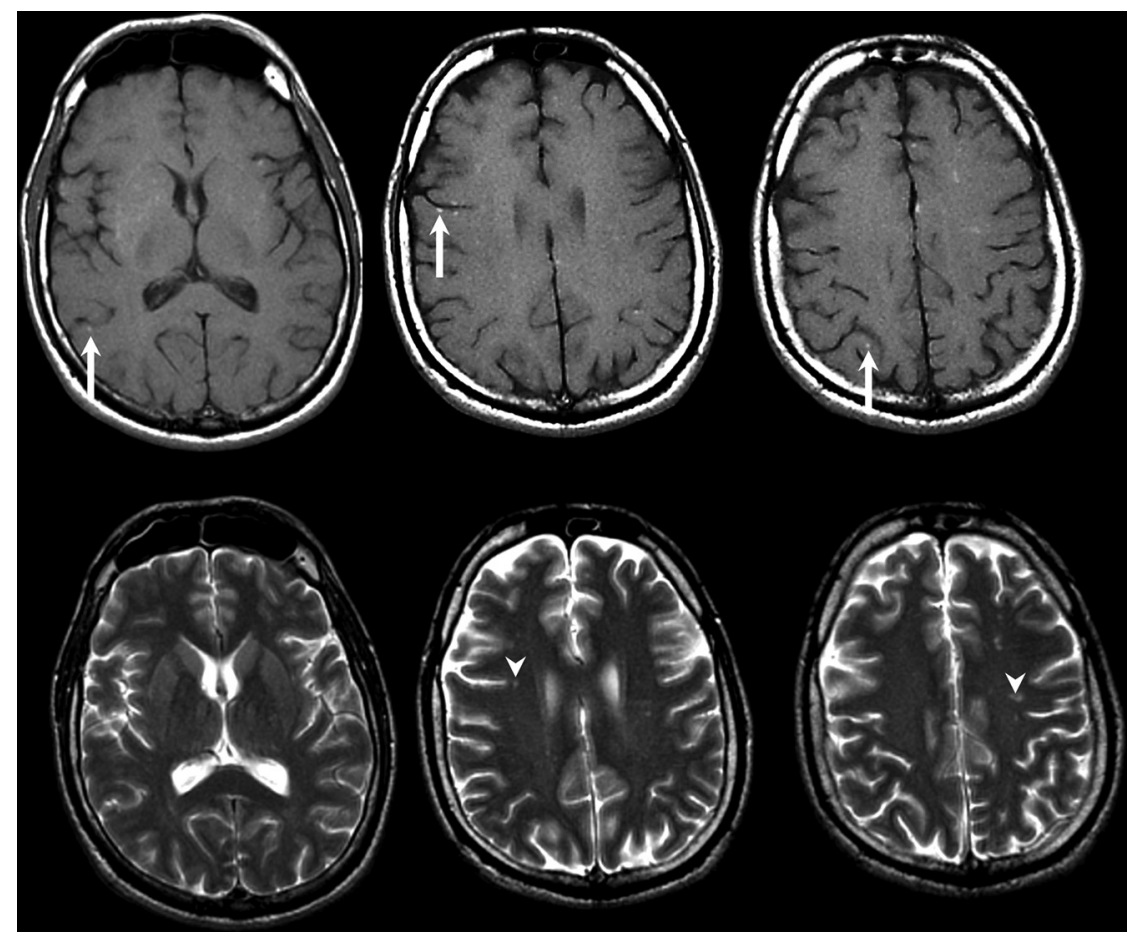

FIG 3. Patient with Nipah virus infection 1 month after infection. Selected axial T1-weighted images (upper row) show multifocal punctate high signal intensity on the cortical surfaces (arrows) as well as in the white matter. These did not enhance after contrast injection and disappeared on 6-month and subsequent follow-up MR imaging (not shown). Selected T2-weighted images (lower row) show noncorresponding multiple tiny focal increased signal intensity (arrowheads) in the white matter. These also became smaller or disappeared on follow-up MR imaging (not shown).

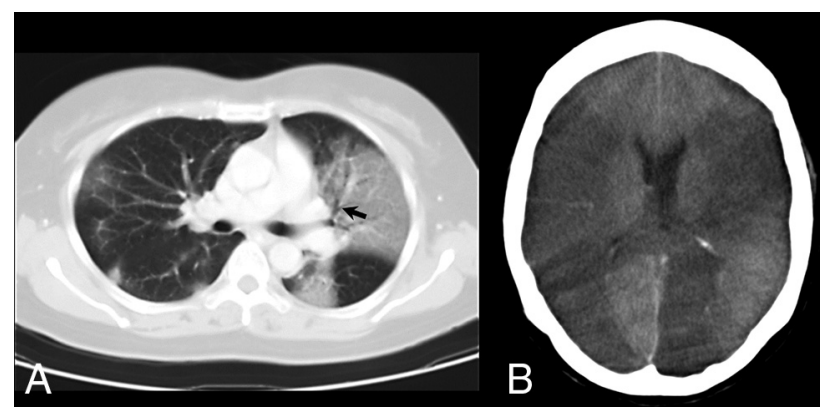

FIG 4. Patient with SARS infection. A, Axial 10-mm-section portable chest CT scan shows multifocal and confluent ground-glass opacities bilaterally with air bronchogram (arrow) in the left upper lobe. B, Axial CT scan of the head shows extensive low-attenuation cerebral infarction involving bilateral middle cerebral and left posterior cerebral artery territories.

\section{Zoonotic Bat-Borne Coronavirus: SARS-CoV and MERS-COV}

SARS-CoV and MERS-CoV are 2 newly discovered $\beta$-coronaviruses and have much more aggressive behavior than the 4 endemic $\alpha$-coronaviruses and discovered $\beta$-coronaviruses, which are known causes of the common cold. ${ }^{41}$ Severe Acute Respiratory Syndrome (SARS) emerged in 2002 in Guangdong province, China, most probably spread via civet cats as intermediate hosts. Human-to-human transmission and global travel rapidly caused the outbreak to spread to a total of 33 nations.
SARS was predominantly an atypical pneumonia with lower respiratory tract infection with limited transmissibility as a rule, yet punctuated by a few superspreading events, and affected 8096 people with 774 deaths. ${ }^{42}$ The SARS outbreak ended in 2003 , and although a small number of cases have occurred as a result of laboratory accidents or through animal-to-human transmission, there have been no large-scale SARS outbreaks since. $^{43}$

CNS manifestations were noted in several seriously ill patients with multiple complications. ${ }^{44}$ Of the 238 patients with SARS in Singapore, 5 had CNS complications, 4 patients were critically ill, and 3 died. ${ }^{45} \mathrm{CT}$ performed in 4 patients showed cerebral infarction involving the large-artery territories (Fig 4), including the middle cerebral artery in all 4 (bilateral in 1) and posterior cerebral artery in 2 ; hemorrhagic conversion was noted in 1 patient. ${ }^{45}$ An increased incidence of pulmonary embolism and deep venous thrombosis was also noted, especially among critically ill patients treated with intravenous immunoglobulin, raising the possibility of a prothrombotic effect. Hence, the role of hypercoagulable state, iatrogenic measures, systemic hypotension, and cardiac dysfunction in seriously ill patients with SARS has been proposed to explain these findings; increased vigilance against stroke and other thrombotic complications in future outbreaks has been recommended. ${ }^{45}$

MERS coronavirus, with camels as intermediate hosts, emerged in 2012 in the Middle East and spread to 26 other nations. ${ }^{15} \mathrm{~A}$ total of 2121 patients were affected in Saudi Arabia, the epicenter of the initial outbreak, and 2519 total cases and 866 deaths have occurred globally since then, with a high case fatality ratio around $35 \%{ }^{46}$ MERS- $\mathrm{CoV}$ presents similar to SARS-CoV in the form of severe respiratory distress, which may progress to shock, acute kidney injury, and coagulopathy. MERS outbreaks in most countries have subsided after infection-control measures but are still simmering with sporadic cases, necessitating maintained hospital vigilance and travel-history screening. ${ }^{46}$ In 1 patient interpreted as having acute disseminated encephalomyelitis, brain MR imaging on day 28 of illness revealed widespread, bilateral, nonenhancing hyperintense lesions on DWI and T2weighted imaging within the frontal, temporal, and parietal subcortical white matter and corpus callosum (Fig 5); other findings included 1 patient with bilateral anterior cerebral artery infarction and another with intracranial hemorrhage. ${ }^{47,48}$ Four of 23 patients affected by the 2015 outbreak in Korea had neurologic symptoms during or after MERS-CoV treatment. These included Bickerstaff encephalitis overlapping with Guillain-Barré 
syndrome and critical illness neuropathy and myopathy; abnormal MR imaging findings were not reported. ${ }^{49}$

\section{Zoonotic Viruses from Putative Bat Hosts and Other Animal Reservoirs}

Both Ebola virus and Marburg virus are members of the Filoviridae family, several of which cause severe hemorrhagic fevers. ${ }^{50,51}$ Extensive surveillance studies have identified bats as a

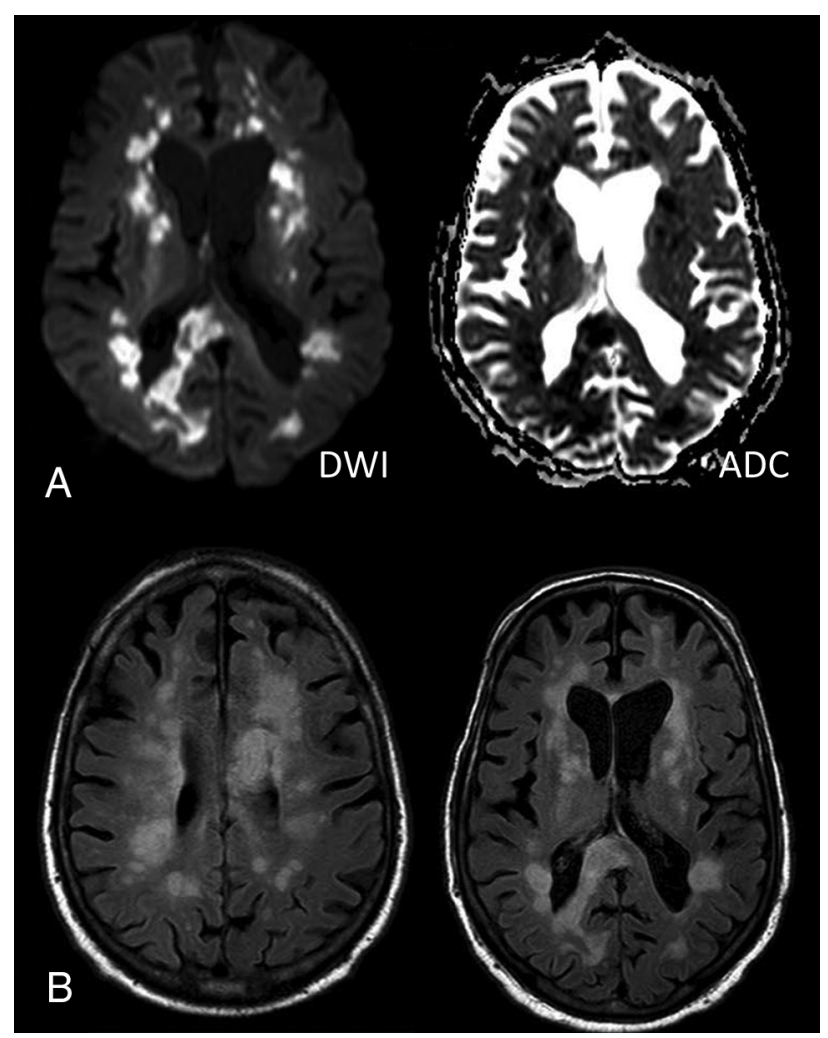

FIG 5. Patient with MERS-CoV infection (on day 28). A, DWI and ADC mapping show diffusion restriction of the multiple white matter lesions. $B$, Axial FLAIR images show multiple hyperintense lesions in the subcortical areas and deep white matter of the frontal, temporal, and parietal lobes bilaterally as well as in the corpus callosum. Images reprinted from Arabi et al. ${ }^{47}$

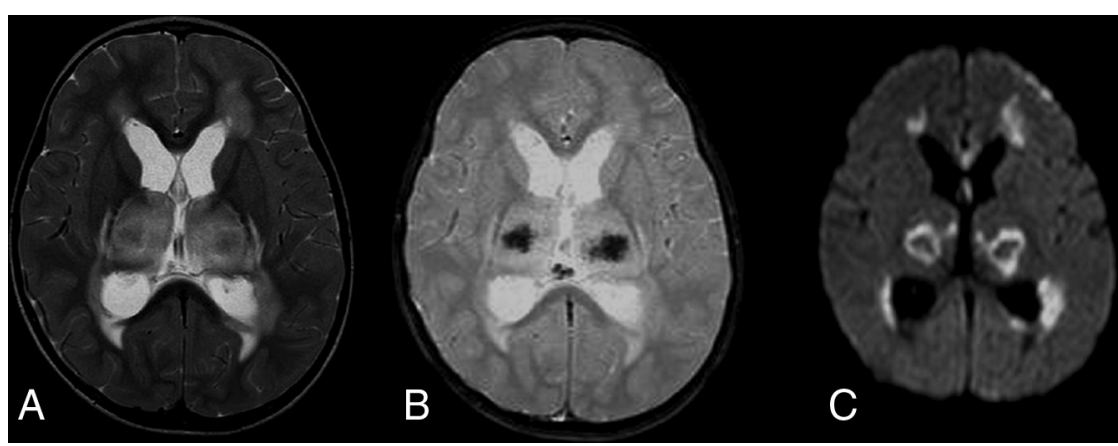

FIG 6. Patient with influenza $A$ HIN1 infection. $A$, Axial T2-weighted image shows symmetric increased signal intensity in the thalami and supratentorial frontal white matter. $B$, T2-weighted gradient-echo image reveals decreased signal intensity in the central portion of the thalami, indicating hemorrhagic necrosis. C, Axial DWI reveals restricted diffusion, with a concentric pattern, symmetrically involving the thalami. Images reprinted from Ormitti et al. ${ }^{54}$ primary reservoir and nonhuman primates as intermediate hosts, with human consumption of bushmeat implicated in localized outbreaks. ${ }^{16}$ Since their discovery, at least 28 Ebola virus outbreaks and 13 Marburg virus outbreaks have occurred in subSaharan Africa, often complicated by armed conflict and hostility to medical support teams; hence, neuroimaging is poorly described. ${ }^{51}$ Patients with Ebola virus typically have bleeding complications, and CNS involvement includes a case report of meningoencephalitis in a seriously ill patient with multiple organ failure. DWI showed multiple punctate lesions in the corpus callosum, cerebral white matter, and spinal cord, reported as consistent with microvascular occlusion and ischemia. There were no hemorrhagic lesions, and results of Ebola virus polymerase chain reaction testing on CSF were negative. ${ }^{52}$

Apart from bat-borne zoonotic viruses, novel influenza A viruses, including those that normally circulate in pigs (H1N1, $\mathrm{H} 1 \mathrm{~N} 2, \mathrm{H} 3 \mathrm{~N} 2$ ), and the highly virulent avian H5N1 and H7N9 viruses, are always threatening to trigger the next pandemic. ${ }^{53}$ However, the recent 2009 influenza A H1N1 pandemic did not result in widespread CNS abnormalities, though a few reports have described brain CT or MR imaging findings. Notably, several reports described bilateral thalamic lesions, some with DWI high signal and focal hemorrhage, consistent with acute necrotizing encephalopathy (Fig 6), as well as patients with meningeal enhancement. ${ }^{54,55}$ New-onset seizures and encephalopathy were found to commonly occur in patients with underlying neurologic disorders, with swelling of bilateral basal ganglia and thalami and cerebral edema and tonsillar herniation noted on MR imaging. ${ }^{56}$ Overall, viruses remain the most likely class of organisms resulting in zoonotic outbreaks affecting the CNS.

\section{Zoonotic Outbreak from Contaminated Raw Fish: Group B Streptococcus ST283}

Group B streptococcus bacteria are common gastrointestinal and genitourinary commensal organisms in humans, and they can cause bacteremia and meningitis in neonates and pregnant women. Invasive group B streptococcus infection is rare in healthy adults, but among patients with chronic underlying comorbidities, ${ }^{57}$ it can cause urinary tract and soft-tissue infection, osteomyelitis, infective endocarditis, and pneumonia, but rarely meningitis. ${ }^{58}$ In 2015 , there was an outbreak of 238 cases of group B streptococcus infections in a foodborne outbreak associated with consumption of Chinese-style raw freshwater fish ${ }^{59}$; 29 patients had meningoencephalitis, fever, meningism, headache, encephalopathy, focal neurologic deficits, and/or seizures.

The invasive serotype III sequence type 283 (ST283) Streptococcus agalactiae was identified as the causative organism, with the same strain identified among farmed freshwater fish used for food preparation. ${ }^{60-62}$ The outbreak stopped after affected fish imports into Singapore were banned and stricter 
rules were established governing raw fish dishes. ${ }^{60}$ However, there have been other, smaller outbreaks of human meningitis in Hong Kong and Southeast Asia involving the ST283 strain, suggesting a potential public health threat of this foodborne zoonosis in Asia. ${ }^{63}$ Other bacteria have caused smaller zoonotic outbreaks in the past, including meningitis from infected unpasteurized dairy products, but the ST283 outbreak demonstrates the need for vigilance and a broader perspective of CNS involvement in zoonotic disease. $^{64}$

DWI showed single or multiple tiny hyperintensities in the subarachnoid space or ventricles, consistent with small amounts of pus (Fig 7). ${ }^{62,65}$ Eight of 14 patients also had DWI lesions in the basal ganglia, corona radiata, thalamus, midbrain, cerebral peduncle and corpus callosum, posterior limb of the internal

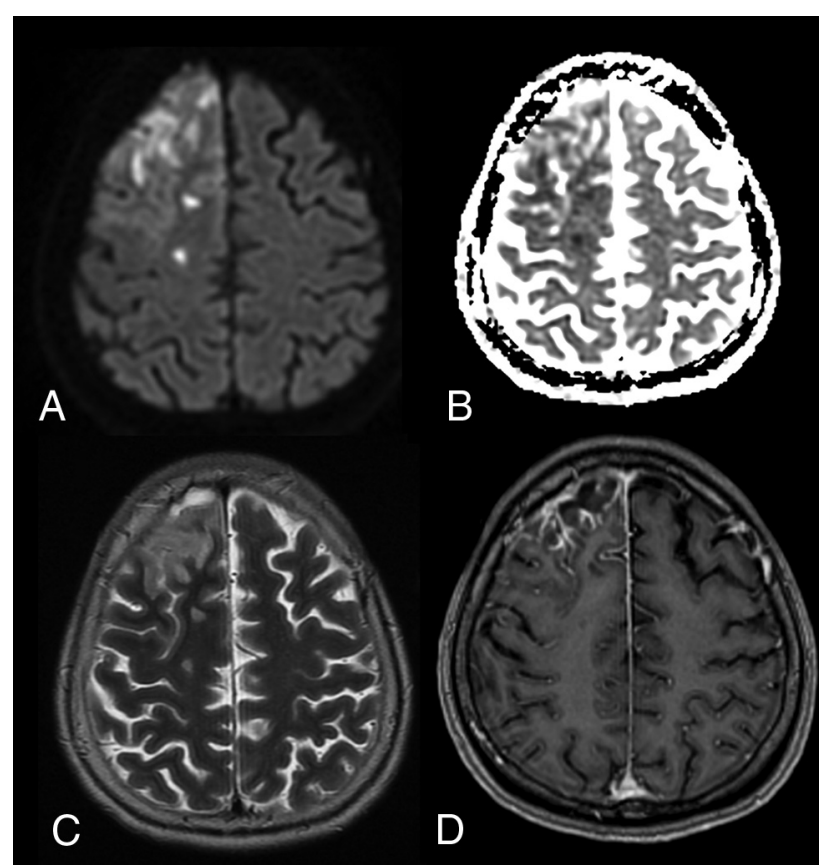

FIG 7. Patient with group B Streptococcus ST283 meningitis. A, Axial DWI shows multifocal high signal intensity in the cortex, white matter, and subarachnoid space of the right frontal lobe. B, ADC map shows corresponding low ADC. C, T2-weighted images show increased signal. $D$, After contrast injection, Tl-weighted images show leptomeningeal enhancement, typical of meningitis. capsule, frontal and parietal cortex, and white matter; 5 had cerebellar involvement. ${ }^{65}$ Hyperintense pus detected by DWI in the subarachnoid space is nonspecific; many bacteria, tuberculosis, or fungi can be responsible. Meningitis may also cause additional MR imaging features such as meningeal enhancement, abscess formation, or hydrocephalus. ${ }^{66}$ However, DWI demonstrated high sensitivity, and tiny subtle abnormalities were either less conspicuous or not visualized on $\mathrm{T} 1$ - or T2-weighted images, suggesting cerebral infarction as a possible mechanism for some of the unusual brain parenchymal involvement. ${ }^{65}$

\section{Observations and Lessons Learned from Past Zoonotic Outbreaks}

Zoonotic and nonzoonotic infections can affect the CNS by different mechanisms, and neuroradiologists may observe 3 broad patterns of changes on CNS imaging in serious infections. First, there may be direct injury to nervous tissue, entering via hematogenous or neuronal invasion and causing damage to the brain and meninges (eg, herpes virus and Streptococcus). ${ }^{41}$ The causative bacterium or virus is usually isolated from the CSF, as has been described in $\mathrm{HeV}$ and $\mathrm{NiV}$ outbreaks; however, in many case reports for SARS-CoV/SARS-CoV-2, MERS-CoV, and the Ebola virus, the causative viruses were not successfully isolated. ${ }^{45,47}$ Second, an immune-mediated response may be responsible for some MR imaging findings, including an early excessive innate immune response such as "cytokine storm" (eg, acute necrotizing encephalopathy similar to cases described in $\mathrm{H} 1 \mathrm{~N} 1)^{67}$ and a late immune response, typically taking place some days or weeks after an acute infection (eg, acute disseminated encephalomyelitis and Guillain-Barré syndrome in the peripheral nervous system) ${ }^{68}$ Finally, CT and MR imaging manifestations may be the result of cerebrovascular complications, pre-existing comorbidities, or iatrogenic effects; these are often seen in critically ill patients in the intensive care unit. Thus, the imaging findings may not be easily categorized or definitively explained because individual patients may sustain CNS damage from multiple mechanisms. ${ }^{6}$

Neuroradiologists must be aware of CNS imaging features of past zoonotic infections to be prepared for current and future pandemics. In this review, we have highlighted CNS imaging in several past zoonotic infectious outbreaks, summarized in Table 2. The patterns of brain abnormalities include widespread cortical or

Table 2: Key brain neuroimaging findings in zoonotic outbreaks

\begin{tabular}{ll}
\hline \multicolumn{1}{c}{ Zoonotic Pathogen } & \multicolumn{1}{c}{ Brain Neuroimaging Abnormalities } \\
\hline Hendra virus (HeV) & Widespread cortex \\
Nipah virus (NiV) & Multifocal tiny white matter and others \\
& Widespread cortex ${ }^{27,34,36}$ \\
SARS-CoV & Large arterial territory infarction (with hemorrhage) \\
MERS-CoV & Multifocal white matter and others \\
& Large arterial territory infarction $^{47 a}$ \\
Ebola virus (EBOV) & Intracranial hemorrhage $^{48}$ \\
Influenza A HIN1 virus & Multifocal tiny white matter and others \\
& Bilateral thalamus (with hemorrhage) and others \\
Streptococcus agalactiae ST283 & Meningeal enhancement \\
& Multifocal subarachnoid space and others \\
\end{tabular}

${ }^{\mathrm{a}}$ Denotes detected on DWI. 
multifocal white matter lesions, large arterial territory infarction, hemorrhage, and meningeal enhancement. Some may be relevant to the current COVID-19 pandemic, and some may eventually turn out not to be relevant or even misleading. Knowledge of typical MR imaging features of bacterial meningitis enabled authors to identify tiny amounts of pus in the subarachnoid space and ventricles in the ST283 group B Streptococcus outbreak with high sensitivity, and knowledge of Japanese encephalitis virus features enabled researchers to eliminate it during the $\mathrm{NiV}$ outbreak. Being open to the possibility of vasculitis-induced and coagulopathic effects of infection enabled the observations in $\mathrm{NiV}$ and SARS. DWI is extremely sensitive to small lesions, though it is challenging to distinguish between ischemic and infective brain damage; however, in an outbreak of infectious disease, the challenges of transportation and acquiring MR imaging in severely ill and intubated patients may mean that CT may be more appropriately used in these situations. ${ }^{45,69}$ Finally, newer MR imaging pulse sequences such as susceptibility-weighted imaging and perfusion MR imaging may contribute to the original research literature on COVID-19, which is still being written.

\section{CONCLUSIONS}

In military history, generals and commanders are cautioned against "fighting the last war" by using outdated equipment, tactics, and concepts and failing to realize that their enemies and situations have changed. Martial language is often used to describe the current pandemic as a war, with troops, frontlines, and victories. Although Mark Twain famously said that history may not repeat itself (in exactly the same manner), it certainly has many common features. Neuroradiologists should recognize the MR imaging and CT imaging features of past zoonotic outbreaks but be prepared to recognize new imaging manifestations as data emerge. As health care professionals worldwide labor to suppress the COVID-19 pandemic, neuroradiologists should not be fighting the last war; we should instead unite and learn together in this unprecedented shared struggle. 5,70

\section{ACKNOWLEDGMENTS}

The authors thank Ms Qianhui Cheng, Mr Shawn Teo Yi En, Dr T. Umapathi, and Dr Ng Yuen Li for their kind contributions.

Disclosures: Lin-Fa Wang-RELATED: Grant: National Research Foundation, Comments: Grants for research from 2013 to 2019.* *Money paid to the institution.

\section{REFERENCES}

1. Wu F, Zhao S, Yu B, et al. A new coronavirus associated with human respiratory disease in China. Nature 2020;579:265-69 CrossRef Medline

2. Mao L, Jin H, Wang M, et al. Neurologic manifestations of hospitalized patients with coronavirus disease 2019 in Wuhan, China. JAMA Neurol 2020;77:683 CrossRef Medline

3. Mackenzie JS. Emerging zoonotic encephalitis viruses: lessons from Southeast Asia and Oceania. J Neurovirol 2005;11:434-40 CrossRef Medline

4. Munoz LS, Garcia MA, Gordon-Lipkin E, et al. Emerging viral infections and their impact on the global burden of neurological disease. Semin Neurol 2018;38:163-75 CrossRef Medline
5. Mahajan A, Hirsch JA. Novel coronavirus: what neuroradiologists as citizens of the world need to know. AJNR Am J Neuroradiol 2020;41:552-54 CrossRef Medline

6. Morris M, Zohrabian VM. Neuroradiologists, be mindful of the neuroinvasive potential of COVID-19. AJNR Am J Neuroradiol 2020;41:E37-E39 CrossRef Medline

7. Parrish CR, Holmes EC, Morens DM, et al. Cross-species virus transmission and the emergence of new epidemic diseases. Microbiol Mol Biol Rev 2008;72:457-70 CrossRef Medline

8. Daszak P, Cunningham AA, Hyatt AD. Emerging infectious diseases of wildlife-threats to biodiversity and human health. Science 2000;287:443-49 CrossRef Medline

9. Jones KE, Patel NG, Levy MA, et al. Global trends in emerging infectious diseases. Nature 2008;451:990-93 CrossRef Medline

10. Prentice MB, Rahalison L. Plague. Lancet 2007;369:1196-207 CrossRef Medline

11. Wang LF, Cowled C. Bats and Viruses: A New Frontier of Emerging Infectious Diseases. 2015. Hoboken, NJ: Wiley

12. Hemachudha T, Laothamatas J, Rupprecht CE. Human rabies: a disease of complex neuropathogenetic mechanisms and diagnostic challenges. Lancet Neurol 2002;1:101-09 CrossRef Medline

13. Field HE. Bats and emerging zoonoses: henipaviruses and SARS. Zoonoses Public Health 2009;56:278-84 CrossRef Medline

14. Wang L, Anderson DE, Mackenzie JS, et al. From Hendra to Wuhan: what has been learned in responding to emerging zoonotic viruses. Lancet 2020;6736:1-2 CrossRef Medline

15. De Wit E, Van Doremalen N, Falzarano D, et al. SARS and MERS: recent insights into emerging coronaviruses. Nat Rev Microbiol 2016;14:523-34 CrossRef Medline

16. Wang LF, Anderson DE. Viruses in bats and potential spillover to animals and humans. Curr Opin Virol 2019;34:79-89 CrossRef Medline

17. Medina RA, García-Sastre A. Influenza A viruses: new research developments. Nat Rev Microbiol 2011;9:590-603 CrossRef Medline

18. Hautala T, Mähönen S-M, Sironen T, et al. Central nervous systemrelated symptoms and findings are common in acute Puumala hantavirus infection. Ann Med 2010;42:344-51 CrossRef Medline

19. Hygino da Cruz LC, Nascimento OJM, Lopes F, et al. Neuroimaging findings of Zika virus-associated neurologic complications in adults. AJNR Am J Neuroradiol 2018;39:1967-74 CrossRef Medline

20. Murray K, Rogers R, Selvey L, et al. A novel morbillivirus pneumonia of horses and its transmission to humans. Emerg Infect Dis 1995;1:31-33 CrossRef Medline

21. O'Sullivan JD, Allworth AM, Paterson DL, et al. Fatal encephalitis due to novel paramyxovirus transmitted from horses. Lancet 1997;349:93-95 CrossRef Medline

22. Eaton BT, Broder CC, Middleton D, et al. Hendra and Nipah viruses: different and dangerous. Nat Rev Microbiol 2006;4:23-35 CrossRef Medline

23. Öztürk A, Gürses C, Baykan B, et al. Subacute sclerosing panencephalitis: clinical and magnetic resonance imaging evaluation of 36 patients. J Child Neurol 2002;17:25-29 CrossRef Medline

24. Chua KB, Goh KJ, Wong KT, et al. Fatal encephalitis due to Nipah virus among pig-farmers in Malaysia. Lancet 1999;354:1-3 CrossRef Medline

25. Paton NI, Leo YS, Zaki SR, et al. Outbreak of Nipah-virus infection among abattoir workers in Singapore. Lancet 1999;354:1253-56 CrossRef Medline

26. Lee KE, Umapathi T, Tan CB, et al. The neurological manifestations of Nipah virus encephalitis, a novel paramyxovirus. Ann Neurol 1999;46:428-32 CrossRef Medline

27. Goh KJ, Tan CT, Chew NK, et al. Clinical features of Nipah virus encephalitis among pig farmers in Malaysia. $N$ Engl $\mathrm{J}$ Med 2000;342:1229-35 CrossRef Medline

28. Rahman MA, Hossain MJ, Sultana S, et al. Date palm sap linked to Nipah virus outbreak in Bangladesh, 2008. Vector-Borne Zoonotic Dis 2012;12:65-72 CrossRef Medline 
29. Ang BSP, Lim TCC, Wang L. Nipah virus infection. J Clin Microbiol 2018;56:e01875-17 CrossRef Medline

30. Ching PK, de Los Reyes VC, Sucaldito MN, et al. Outbreak of henipavirus infection, Philippines, 2014. Emerg Infect Dis 2015;21:32831 CrossRef Medline

31. Lim CCT, Sitoh YY, Hui F, et al. Nipah viral encephalitis or Japanese encephalitis? MR findings in a new zoonotic disease. AJNR Am J Neuroradiol 2000;21:455-61 Medline

32. Lim CC, Sitoh YY, Lee KE, et al. Meningoencephalitis caused by a novel paramyxovirus: an advanced MRI case report in an emerging disease. Singapore Med J 1999;40:356-58 Medline

33. Lim CC, Lee WL, Leo YS, et al. Late clinical and magnetic resonance imaging follow up of Nipah virus infection. J Neurol Neurosurg Psychiatry 2003;74:131-33 CrossRef Medline

34. Sarji SA, Abdullah BJJ, Goh KJ, et al. MR imaging features of Nipah encephalitis. AJR Am J Roentgenol 2000;175:437-42 CrossRef Medline

35. Tan CT, Goh KJ, Wong KT, et al. Relapsed and late-onset Nipah encephalitis. Ann Neurol 2002;51:703-08 CrossRef Medline

36. Sejvar JJ, Hossain J, Saha SK, et al. Long-term neurological and functional outcome in Nipah virus infection. Ann Neurol 2007;62:235-42 CrossRef Medline

37. Abdullah S, Chang LY, Rahmat K, et al. Late-onset Nipah virus encephalitis 11 years after the initial outbreak: a case report. Neurol Asia 2012;17:71-74

38. Chua KB, Bellini WJ, Rota PA, et al. Nipah virus: a recently emergent deadly paramyxovirus. Science 2000;288:1432-35 CrossRef Medline

39. Wong KT, Robertson T, Ong BB, et al. Human Hendra virus infection causes acute and relapsing encephalitis. Neuropathol Appl Neurobiol 2009;35:296-305 CrossRef Medline

40. Wong KT, Shieh WJ, Kumar S, et al. Nipah virus infection: pathology and pathogenesis of an emerging paramyxoviral zoonosis. $\mathrm{Am}$ J Pathol 2002;161:2153-67 CrossRef Medline

41. Matías-Guiu J, Gomez-Pinedo U, Montero-Escribano P, et al. Should we expect neurological symptoms in the SARS-CoV-2 epidemic? Neurologia 2020;35:170-75 CrossRef Medline

42. Ruan S. Likelihood of survival of coronavirus disease 2019. Lancet Infect Dis 2020;20:630-31 CrossRef Medline

43. Wong TW. "Will the SARS epidemic recur?" A retrospective analysis of the experts' opinions. J Epidemiol Community Health 2006;60:87 Medline

44. Lau K, Yu W, Chu C, et al. Possible central nervous system infection by SARS coronavirus. Emerg Infect Dis 2004;10:2-4 CrossRef Medline

45. Umapathi T, Kor AC, Venketasubramanian N, et al. Large artery ischaemic stroke in severe acute respiratory syndrome (SARS). $J$ Neurol 2004;251:1227-31 CrossRef Medline

46. World Health Organization. MERS situation update. 2020. https:// applications.emro.who.int/docs/EMCSR254E.pdf?ua=1\&ua=1. Accessed May 12, 2020

47. Arabi YM, Harthi A, Hussein J, et al. Severe neurologic syndrome associated with Middle East respiratory syndrome corona virus (MERS-CoV). Infection 2015;43:495-501 CrossRef Medline

48. Algahtani H, Subahi A, Shirah B. Neurological complications of Middle East respiratory syndrome coronavirus: a report of two cases and review of the literature. Case Rep Neurol Med 2016;2016:1-6 CrossRef Medline

49. Kim JE, Heo JH, Kim HO, et al. Neurological complications during treatment of Middle East respiratory syndrome. J Clin Neurol 2017;13:227-33 CrossRef Medline

50. Brauburger K, Hume AJ, Mühlberger E, et al. Forty-five years of Marburg virus research. Viruses 2012;4:1878-927 CrossRef Medline
51. Malvy D, McElroy AK, de Clerck H, et al. Ebola virus disease. Lancet 2019;393:936-48 CrossRef Medline

52. Chertow DS, Nath A, Suffredini AF, et al. Severe meningoencephalitis in a case of Ebola virus disease: a case report. Ann Intern Med 2016;165:301-04 CrossRef Medline

53. Neumann G, Kawaoka Y. Predicting the next influenza pandemics. J Infect Dis 2019;219:S14-20 CrossRef Medline

54. Ormitti F, Ventura E, Summa A, et al. Acute necrotizing encephalopathy in a child during the 2009 influenza $A(H 1 N 1)$ pandemia: MR imaging in diagnosis and follow-up. AJNR Am J Neuroradiol 2010;31:396-400 CrossRef Medline

55. Zeng H, Quinet S, Huang W, et al. Clinical and MRI features of neurological complications after influenza A (H1N1) infection in critically ill children. Pediatr Radiol 2013;43:1182-89 CrossRef Medline

56. Prerna A, Lim JY, Tan NW, et al. Neurology of the H1N1 pandemic in Singapore: a nationwide case series of children and adults. $J$ Neurovirol 2015;21:491-99 CrossRef Medline

57. Skoff TH, Farley MM, Petit S, et al. Increasing burden of invasive group B streptococcal disease in nonpregnant adults, 1990-2007. Clin Infect Dis 2009;49:85-92 CrossRef Medline

58. Oyanguren B, Esteban L, Guillán M, et al. Central nervous system involvement in adult patients with invasive infection caused by Streptococcus agalactiae. Neurologia 2015;30:158-62 CrossRef Medline

59. Tan S, Lin Y, Foo K, et al. Group B streptococcus serotype III sequence type 283 bacteremia associated with consumption of raw fish, Singapore. Emerg Infect Dis 2016;22:1970-73 CrossRef Medline

60. Chau ML, Chen SL, Yap M, et al. Group B Streptococcus infections caused by improper sourcing and handling of fish for raw consumption, Singapore, 2015. Emerg Infect Dis 2017;23:1982-90 CrossRef Medline

61. Wang R, Li L, Huang YY, et al. Pathogenicity of human ST23 Streptococcus agalactiae to fish and genomic comparison of pathogenic and non-pathogenic isolates. Front Microbiol 2017;8:1-11 CrossRef Medline

62. Kalimuddin S, Chen SL, Lim CTK, et al. 2015 epidemic of severe streptococcus agalactiae sequence type 283 infections in Singapore associated with the consumption of raw freshwater fish: a detailed analysis of clinical, epidemiological, and bacterial sequencing data. Clin Infect Dis 2017;64:S145-52 CrossRef Medline

63. Ip M, Cheuk ESC, Tsui MHY, et al. Identification of a Streptococcus agalactiae serotype III subtype 4 clone in association with adult invasive disease in Hong Kong. J Clin Microbiol 2006;44:4252-54 CrossRef Medline

64. van Samkar A, Brouwer MC, van der Ende A, et al. Zoonotic bacterial meningitis in human adults. Neurology 2016;87:1171-79 CrossRef Medline

65. Tan K, Wijaya L, Chiew H-J, et al. Diffusion-weighted MRI abnormalities in an outbreak of Streptococcus agalactiae serotype III, multilocus sequence type $\mathbf{2 8 3}$ meningitis. J Magn Reson Imaging 2017;45:507-14 CrossRef Medline

66. Kawaguchi T, Sakurai K, Hara M, et al. Clinico-radiological features of subarachnoid hyperintensity on diffusion-weighted images in patients with meningitis. Clin Radiol 2012;67:306-12 CrossRef Medline

67. Poyiadji N, Shahin G, Noujaim D, et al. COVID-19-associated acute hemorrhagic necrotizing encephalopathy: CT and MRI features. Radiology 2020;296:E119-20 CrossRef Medline

68. Tchoyoson LCC. Neuroimaging in postinfectious demyelination and nutritional disorders of the central nervous system. Neuroimaging Clin North Am 2011;21:843-58 CrossRef Medline

69. Schaefer PW, Grant PE, Gonzalez RG. Diffusion-weighted MR imaging of the brain. Radiology 2000;217:331-45 CrossRef Medline

70. Lim CCT, Tsuchiya K. "No Man is an Island" John Donne. AJNR Am J Neuroradiol 2020;349:6544 CrossRef Medline 